\title{
Effect of shell as natural testosterone boosters in Sprague Dawley rats
}

\author{
Pudji Astuti ${ }^{1}$, Claude Mona Airin ${ }^{1}$, Sarmin Sarmin ${ }^{1}$, Alfarisa Nururrozi ${ }^{2}$ and Sri Harimurti ${ }^{3}$
}

1. Department of Physiology, Faculty of Veterinary Medicine, Universitas Gadjah Mada, Yogyakarta, Indonesia; 2. Department of Internal Medicine, Faculty of Veterinary Medicine, Universitas Gadjah Mada, Yogyakarta, Indonesia;

3. Department of Poultry Science, Faculty of Animal Science, Universitas Gadjah Mada, Yogyakarta, Indonesia. Corresponding author: Pudji Astuti, e-mail: pastuti2@ugm.ac.id

Co-authors: CMA: monaairin@ugm.ac.id, SS: sarminkh76@ugm.ac.id, AN: alfarisa.nururrozi@ugm.ac.id, SH: sriharimurtibasyar@yahoo.com

Received: 16-04-2019, Accepted: 12-09-2019, Published online: 30-10-2019

doi: www.doi.org/10.14202/vetworld.2019.1677-1681 How to cite this article: Astuti P, Airin CM, Sarmin S, Nururrozi A, Harimurti S (2019) Effect of shell as natural testosterone boosters in Sprague Dawley rats, Veterinary World, 12(10): 1677-1681.

\begin{abstract}
Aim: This study aimed to evaluate the effect of shell supplementation on the regulation of male reproduction in rats.

Materials and Methods: The zinc (Zn) level of shell from blood clam (Anadara granosa), green mussel (Perna viridis), and conch shell (Telescopium telescopium) was analyzed. The highest $\mathrm{Zn}$ content shell was fed to male Sprague Dawley rats for $0,9,30$, and 50 days at the dose of either $0.09 \mathrm{mg} / 200 \mathrm{~g} \mathrm{BW}$ or $0.18 \mathrm{mg} / 200 \mathrm{~g} \mathrm{BW}$. To determine the testosterone levels, blood was collected through the infraorbitalis sinus just before the rat was sacrificed. Testicular and brain were also collected for Cyp19 aromatase receptor analysis.

Results: The Zn level in the shell of blood clam, green mussel, and conch shell $61.55 \mathrm{mg} / \mathrm{kg}, 2.78 \mathrm{mg} / \mathrm{kg}$, and $3.93 \mathrm{mg} / \mathrm{kg}$, respectively. The testosterone level of T1 group receiving $0.18 \mathrm{mg} / 200 \mathrm{~g} \mathrm{BW}$ for $0,9,30$, and 50 days was $1.42 \pm 0.59$, $2.15 \pm 1.58,2.98 \pm 2.53$, and $8.11 \pm 2.03 \mathrm{ng} / \mathrm{mL}$, respectively. The testosterone level of $\mathrm{T} 2$ group receiving $0.09 \mathrm{mg} / 200 \mathrm{~g}$ BW for $0,9,30$, and 50 days was $2.50 \pm 0.32,1.25 \pm 0.60,3.87 \pm 3.27$, and $3.54 \pm 0.23 \mathrm{ng} / \mathrm{mL}$, respectively. The T3 group receiving $\mathrm{Na}-\mathrm{CMC}$ showed the level of testosterone at days $0,9,30$, and 50 days was $0.77 \pm 0.22,1.99 \pm 1.65,4.12 \pm 0.07$, and $2.19 \pm 1.30 \mathrm{ng} / \mathrm{mL}$, respectively. Finally, the T4 group receiving Zn showed testosterone levels at days 0, 9, 30, and 50 days was $0.51 \pm 0.58,2.24 \pm 3.16,4.58 \pm 1.97$, and $2.89 \pm 0.20 \mathrm{ng} / \mathrm{mL}$, respectively. There was a significant difference $(\mathrm{p}<0.05)$ between the T1 group compared to the other groups. However, the absence of expression of Cyp19 aromatase both in Leydig cells and the brain indicated no conversion of testosterone to estradiol. To add, this finding showed the potential use of the shell to boost the testosterone level in male rats.
\end{abstract}

Conclusion: Shell acted as an aromatase blocker to boost the testosterone level in male rats. This also indicates its promising application in birds to manipulate the quality of song and feather.

Keywords: Cyp19, shell, testosterone, zinc.

\section{Introduction}

Shellfish is an abundant product, especially in Eastern Indonesia. In addition to its delicious taste, shellfish also contains numerous vitamins and nutrients. Approximate composition of fatty acid, amino acid profiles, and mineral content has been determined in oysters (Crassostrea madrasensis). The moisture protein, fat, carbohydrate, and ash content in oysters are $82.64 \%, 9.41 \%, 3.25 \%, 3.2 \%$, and $1.01 \%$, respectively. They are rich in macrominerals and trace elements, especially zinc ( $\mathrm{Zn}$ ) and selenium. Polyunsaturated fatty acids are the most common lipid including eicosapentaenoic acid, docosahexaenoic acid, and linoleic acid [1]. $\mathrm{Zn}$ is also very important and can be used as an aphrodisiac; a stimulant of enzymes, hormones, and the immune system. Since

Copyright: Astuti, et al. Open Access. This article is distributed under the terms of the Creative Commons Attribution 4.0 International License (http://creativecommons.org/licenses/by/4.0/), which permits unrestricted use, distribution, and reproduction in any medium, provided you give appropriate credit to the original author(s) and the source, provide a link to the Creative Commons license, and indicate if changes were made. The Creative Commons Public Domain Dedication waiver (http://creativecommons.org/ publicdomain/zero/1.0/) applies to the data made available in this article, unless otherwise stated. shellfish is abundant, the value of discarded shells waste has not much been explored.

If shellfish contains various nutrients, it is estimated that the shell may also contain the same nutrients, especially $\mathrm{Zn}$. $\mathrm{Zn}$ is one of the macrominerals that function to increase testosterone levels both in humans and in mammals. It is indicated that $\mathrm{Zn}$ works by reducing the aromatase enzyme Cyp19, an enzyme that converts testosterone to estradiol. Chu et al. [2] study on Leydig cells in mice found that $\mathrm{Zn}$ transporters (ZnT7) may play an important role in the regulation of testosterone synthesis by modulating steroidogenic (STARs) enzymes and may represent as therapeutic target in testosterone deficiency. In singing birds, testosterone levels influence the quality of sound and feathers. Sankako et al. [3] reported that testosterone level will increase if aromatase enzyme is blocked since the conversion of testosterone to estrogen is inhibited. Salehi et al. [4] found that testosterone level of certain snakes living in four seasons is greatly affected by spermatogenesis and body weight. Reed et al. [5] found that $\mathrm{Zn}$ influenced the digestive system of chickens. Birds with Zn deficiency tend to experience digestive disorders. 
This study aimed to determine the effect of shellfish supplementation on the regulation of male rat reproduction by measuring the level of testosterone in serum, Cyp19 expression in testicular and brain by immunohistochemistry. If the results showing a significant effect, it will then apply to sing birds to improve the quality of sound and feathers.

\section{Materials and Methods}

\section{Ethical approval}

The Ethics Committee of the Integrated Testing and Research Laboratory, Universitas Gadjah Mada (UGM), certificate number 00023/04/LPPT/IV/2018 approved all procedures.

\section{Shell origin and analysis}

Three shells from blood clams (Anadara granosa), green mussels (Perna viridis), and conch shells (Telescopium telescopium) were analyzed. The shells were collected from Samas and Glagah Beach, Yogyakarta Special Region, Indonesia. Identification of shellfish species was carried out at the Department of Biology, Universitas Gadjah Mada (UGM), Yogyakarta, Indonesia. The production of shell powder and the analysis of macrominerals contents were carried out using inductively coupled plasma at the Integrated Testing and Research Laboratory, UGM, Yogyakarta, Indonesia. Shell with the highest Zn content then continued for in vivo analysis.

\section{Animals for in vivo study}

The animals used in the study were Sprague Dawley male rats at 1 month of age. Animals were divided into four groups: $\mathrm{T} 1$ received $0.18 \mathrm{mg} / 200 \mathrm{~g} \mathrm{BW}$ shell powder of A. granosa; T2 received $0.09 \mathrm{mg} / 200 \mathrm{~g} \mathrm{BW}$ of $A$. granosa; T3 received $\mathrm{Na}-\mathrm{CMC}$; and $\mathrm{T} 4$ received $\mathrm{Zn} \mathrm{0.09/200 \textrm {g }}$ BW orally. The blood was withdrawn by infraorbital vein at 9, 30, and 50 days post-treatment; then, animals were sacrificed.

\section{Testosterone analysis}

The serum was separated through centrifugation at $3000 \mathrm{rpm}$ for $15 \mathrm{~min}$ and stored at $-20^{\circ} \mathrm{C}$ before used. Samples were then analyzed using ELISA method.

\section{Immunohistochemical staining methods}

Collected testicular and brain were fixed in $10 \%$ PBS-formalin solution for 18-24 $\mathrm{h}$ then embedded in paraffin. The paraffin blocks were then cut to a thickness of $4 \mu$, placed on slides, coated with polyL-Lysine $\left(\right.$ Sigma $\left.^{\circledR}\right)$, and probed with monoclonal antibody Cyp19 aromatase (C-16) SC-14245 (Santa Cruz Biotechnology) at 1:100 of dilution. Subsequently, secondary biotinylated antibody at 1:100 dilution was applied, labeled with strept-enzyme-avidin peroxidase, and mounted with Canada balsam. Brown stained cells indicated the expression of Cyp19 aromatase.

\section{Statistical analysis}

Data were analyzed using SPSS statistical software (IBM, USA) and average data were compared using one-way ANOVA and Duncan test with a confidence level of 0.05 . The immunohistochemical staining results of Cyp19 receptors from testicular and brain were analyzed descriptively.

\section{Results}

\section{Macromineral contents of shell}

The macrominerals contain in shell and meat of shellfish used in this research are listed in Table-1.

Although clams contained various types of macromineral, only $\mathrm{Zn}$ will be further investigated as a potential aromatase blocker. However, $\mathrm{Zn}$ analysis showed Anadara granose shell contained the highest Zn compared to others.

\section{The effect of shell to testosterone level}

$\mathrm{Zn}$ contained oyster meat can improve testosterone levels in humans [6]. It is known that aromatization plays an important role in the testosterone signaling pathway of the brain. Furthermore, estrogen metabolite along with testosterone regulates and activates masculine neural circuit [7].

The result showed post-administration of shell powder for 50 days, the testosterone level was increased either in the control or treatment group (Table-2). Significant difference was observed between control (Na-CMC) and $\mathrm{T} 1$ (Zn $0.18 \mathrm{mg} / 200 \mathrm{~g}$ ) and T4 $(0.09 \mathrm{mg} / 200 \mathrm{~g})$ group.

\section{The expression of Cyp19 aromatase in Leydig cells}

The Cyp19 aromatase of Leydig cells in the control group (Na-CMC) was highly expressed (Figure-1a). However, Cyp19 aromatase in the treatment group at $0.18 \mathrm{mg} / 200 \mathrm{~g}$ was poorly expressed (Figure-1b). Moreover, a similar result also obtained from the pure $\mathrm{Zn}$-treated group.

According to Sankako et al. [3], Zn works as an aromatase blocker; therefore, the conversion of

Table-1: The macrominerals contain in shell and meat of blood clam, green mussel, and conch shell.

\begin{tabular}{|c|c|c|c|c|c|c|}
\hline Oyster shell & $\mathrm{Zn}(\mathrm{mg} / \mathbf{k g})$ & $\mathrm{Mg}(\mathrm{mg} / \mathbf{k g})$ & $\mathrm{Ca}(\mathrm{mg} / \mathrm{dL})$ & $\mathrm{Na}(\mathrm{mg} / \mathrm{kg})$ & $\mathrm{Fe}(\mathrm{mg} / \mathrm{kg})$ & $K(\mathrm{mg} / \mathrm{kg})$ \\
\hline A. granosa & 61.55 & 1666.09 & 41.4 & 9262.98 & 600.54 & 369.29 \\
\hline P. viridis & 2.78 & 141.37 & 55.58 & 8385.29 & 3.99 & 174.23 \\
\hline T. telescopium & 3.93 & 151.23 & 47.15 & 7793.41 & 8.5 & 164.91 \\
\hline Oyster meat & Zn (mg/kg) & $M g(\mathbf{m g} / \mathbf{k g})$ & $\mathrm{Ca}(\mathrm{mg} / \mathrm{dL})$ & $\mathrm{Na}(\mathrm{mg} / \mathbf{k g})$ & $\mathrm{Fe}(\mathrm{mg} / \mathrm{kg})$ & $K(\mathrm{mg} / \mathrm{kg})$ \\
\hline A. granosa & 102.27 & 14.08 & 370.81 & 618.77 & 57.78 & 334.41 \\
\hline P. viridis & 64.23 & 14.06 & 1297.58 & 463.76 & 771.34 & 281.14 \\
\hline T. telescopium & 169.68 & 164.49 & 615.18 & 1558.05 & 32.05 & 1394.75 \\
\hline
\end{tabular}

A. granosa=Anadara granosa, $P$. viridis=Perna viridis, $T$. telescopium $=$ Telescopium telescopium, $\mathrm{Zn}=\mathrm{Zinc}$ 
Table-2: The average of testosterone levels at days $0,9,30$, and 50 after treatment.

\begin{tabular}{lcccc}
\hline Treatment groups & \multicolumn{4}{c}{ Average \pm SE level of testosterone on days $(\mathbf{n g} / \mathbf{m L})$} \\
\cline { 2 - 5 } & $\mathbf{0}$ & $\mathbf{9}$ & $\mathbf{3 0}$ & $\mathbf{5 0}$ \\
\hline T1 $(\mathrm{Zn} 0.18 \mathrm{mg} / 200 \mathrm{~g})$ & $1.42 \pm 0.59$ & $2.15 \pm 1.58$ & $2.98 \pm 2.53$ & $8.11 \pm 2.03 *$ \\
T2 $(\mathrm{Zn} 0.09 \mathrm{mg} / 200 \mathrm{~g})$ & $2.50 \pm 0.32$ & $1.25 \pm 0.60$ & $3.87 \pm 3.27$ & $3.54 \pm 0.23$ \\
T3 $(\mathrm{Na}-\mathrm{CMC})$ & $0.77 \pm 0.22$ & $1.99 \pm 1.65$ & $4.12 \pm 0.07$ & $2.19 \pm 1.30$ \\
T4 $(\mathrm{Zn} 0.09 \mathrm{mg} / 200 \mathrm{~g})$ & $0.51 \pm 0.58$ & $2.24 \pm 3.16$ & $4.58 \pm 1.97$ & $2.89 \pm 0.20 *$ \\
\hline
\end{tabular}

*Significantly different $(P>0.05)$. Zn=Zinc

testosterone into estrogen is inhibited. This was confirmed in the level of testosterone between treatments compared to control after 50 days of shell administration, which was significantly different $(\mathrm{p}<0.05)$.

\section{The expression of Cyp19 aromatase in brain}

Aromatase can also be found in the vertebrate brain from fish to primate, particularly in the brain cell related to hypothalamus reproduction. This research showed a high expression of Cyp19 aromatase receptors in the brain cells of the control group, vice versa of the treatment group (Figure-2). Negative expression of Cyp19 aromatase indicated the role of the shell as aromatase blocker resulted in a high level of testosterone.

The effects of Cyp19 aromatase on spermatogenesis

The Cyp19 aromatase in spermatozoa cell after administration of shell was persistently expressed, although poor expression was showed in Leydig and brain (Figure-3). This indicated the use of estradiol in the development of the reproduction system.

Ninety years ago, Hess and Cooke [8] reported that estradiol for men is considered useless, however, now has been proven that the mainestrogen receptor 1 (ESR1) plays an important role in male fertility and the development of efferent channels, epididymis, prostate, and spermatozoa maturation [9]. Conversely, women also respond to exogenous testosterone, i.e., growth of body hair even though short [10].

\section{Discussion}

$\mathrm{Zn}$ supplement plays an important role as an antioxidant by protecting the concentration of sulfhydryl (SH). Zn-deficient mice have lower testosterone levels compared to normal mice [11]. Furthermore, a low level of testosterone is associated with infertility in humans [12]. Besides the reduction of testosterone level, $\mathrm{Zn}$ deficiency is associated with impaired spermatogenesis due to the elevation of oxidative stressor and apoptosis. $\mathrm{Zn}$ is capable of increasing testosterone through aromatase inhibition mechanism by blocking the conversion of testosterone to estradiol [3]. Letrozole, an aromatase blocker, can increase testosterone both in rats and old rooster in different pathways. In rats, letrozole can increase of gonadotropins due to lack of estrogen $[13,14]$. Similar results to Taxadrol (aromatase blocker), it used to be traditional hormone therapy to increase testosterone [15]. This finding shows that $\mathrm{Zn}$ plays an important role in male reproduction process [16]. The induction of testosterone to a female robin bird

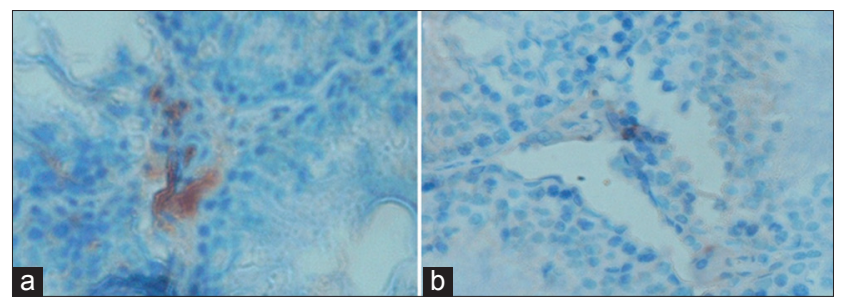

Figure-1: Expression of Cyp19 aromatase in Leydig cells of the control group (a). Negative expression of Cyp19 aromatase in T1 receiving $0.18 \mathrm{mg} / 200 \mathrm{~g} \mathrm{BW}$ (b). Aromatase expression indicated inhibition of testosterone conversion activity.

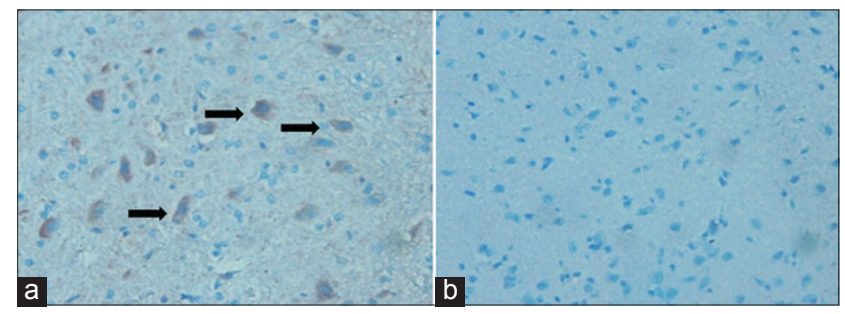

Figure-2: Negative expression of Cyp19 aromatase in the brain of the control group (a), a group of shellfish with a dose of $0.18 \mathrm{mg} / \mathrm{BW}$ (b), where no expression of Cyp19 aromatase indicated no conversion of testosterone to estrogen.

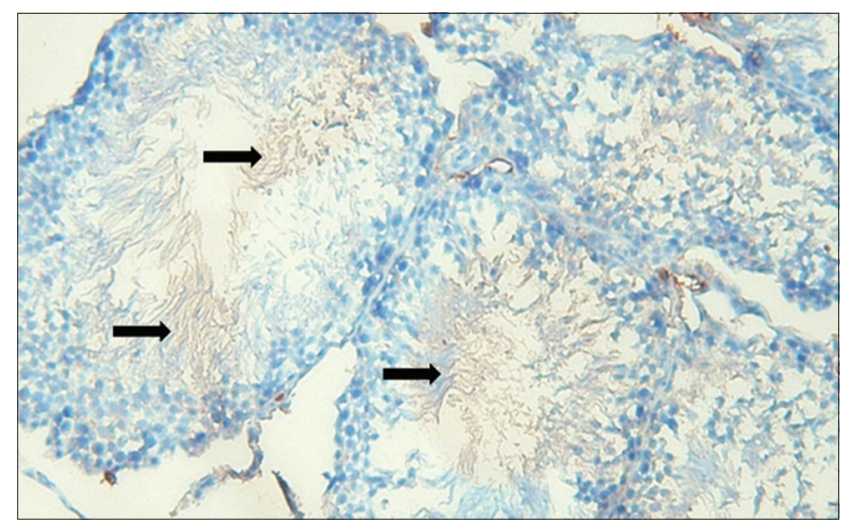

Figure-3: The expression of aromatase Cyp19 on spermatozoa (brown color) indicating that estradiol is needed in the survival process of spermatozoa.

is correlated to the cellular differentiation process in the higher vocal center [17].

\section{The effect of oyster shells on expression Cyp19 aro- matase in Leydig cells}

Aromatase is known as estrogen synthetase, a key enzyme in estrogen biosynthesis. The enzyme is located within the endoplasmic reticulum encoded by 
the Cyp19A gene [18]. This gene belongs to the family of the CYP gene, which encodes a class of active enzymes in the hydroxylation of endogenous and exogenous substances [19]. Aromatase receptors are located in bone, brain, and adipose tissues [9]. The administration of exogenous testosterone or letrozole aromatase inhibitor can improve spermatogenesis disorder which affecting testicular phenotype [20]. Adeldust et al. [21] stated that animals treated with letrozole showed a higher number of spermatozoa cells in the tubules and seminiferous epididymis compared to control animals. Paracrine signaling of the aromatase enzyme is very important in spermatogenesis [9].

Testosterone is naturally produced in Leydig cells. However, this research showed weak expression of Cyp19 aromatase in the control group, which indicated low estrogen but high testosterone level (Figure-3). Boulanger et al. [20] reported a reduction of testosterone and increment of estradiol levels up to 3 times in Celf1-/- mouse testicles during hyperactive aromatase activity. Rosati et al. [22] reported similar conditions of aromatase $\mathrm{P} 450$ presentation in somatic cells and testicular germinal Podarcis sicula (spermatids and spermatozoa) except in early autumn where aromatase is only evident in Leydig cell. Ogunlesi et al. [23] reported Momordica charantia, Neoregelia laevis, and Rauvolfia vomitoria as sources of $\mathrm{Zn}$ and Vitamin $\mathrm{C}$. These plants have been used to treat infertility in men.

\section{The effect of oyster shells on expression of Cyp19 aromatase in brain}

Testosterone can regulate physical activity in male rats through the dopamine agonist pathway by both directly through the androgen receptor (AR) and indirectly through the aromatization of testosterone to estrogen [24]. Antonio-Cabrera and Paredes [25] reported the induction of mating in male rats implanted with testosterone or estradiol at the medial preoptic region. This indicated that a lack of sexual behavior is associated with hormonal changes. The highest aromatase activity is in the neuroendocrine region, which consists of the posteromedial amygdala nucleus, the encapsulation region of the terminal stria nucleus, the bed nucleus of the stria terminalis (BNST), the ventrolateral portion of the ventromedial hypothalamic nucleus, and the central component of the medial preoptic nucleus. Besides, endocrine circuits in the brain also contain estrogen-ARs [26].

\section{The effect of Cyp19 aromatase on spermatogenesis}

Kumar and Singh [27] proposed the aromatase blocker effect of $\mathrm{Zn}$ in tackling male infertility. Furthermore, Zn deficiency inhibits spermatogenesis and increases abnormal sperms. It also proved to have a negative effect on the concentration of testosterone in serum. Thus, $\mathrm{Zn}$ is considered beneficial for prevention, treatment, and diagnostic marker in male infertility [28]. Stocco [9] reported high aromatase activity in mice Sertoli cells before sexual maturity then become prominent in Leydig cells of adult animals. Schulster et al. [29] reported a complex balance of testosterone, estradiol aromatase, and ER in testicular, penis, and brain. This confirms that estrogen is required and well regulated in men. ER and aromatase shared topographical locations with pheromones in the brain and it is clear that estrogen contributes to sexual early development and behavior. The absence of estradiol ESR1 and 17 beta membrane fractions can induce male reproduction abnormalities to infertility [7]. The testes produce large amounts of estradiol associated with aromatase in several cell types. Stocco [9] reported that aromatase mRNA can be detected in spermatogonia gonocytes, preleptotene spermatocytes, and at all stages of the development of cell germ [18]. Low testosterone levels can cause abnormalities of muscle and bone development, loss of strength, energy, and sexual drive together with sperm count declined [30]. Testosterone also affecting the reproductive system of female birds by increasing the secretion of the luteinizing hormone, follicle growth, laying eggs, and the need to build nests [31]. However, the age and environment are important factors that modulate the effects of both endogenous and exogenous sex hormones [32]. Hau et al. [33] stated that the peak of testosterone during the mating season is higher in shortlived species with high mating efforts because this hormone is known to promote male fecundity.

\section{Conclusion}

Administration of shell powder at $0.18 \mathrm{mg} / 200 \mathrm{~g}$ of body weight can increase testosterone levels in mice and block the expression of Cyp19 aromatase. Shell powder can be employed to promote testosterone level through aromatase blocker mechanism. Since estradiol is required in the development of vas deferens, epididymis, and prostate gland, aromatase blocker administration is suggested only for adult animals.

\section{Authors' Contributions}

PA planned the study and drafted the manuscript, designed the experiment protocol. CMA and AN collected and analyzed samples. SS revised the manuscript under the supervision of PA and SH. All authors read and approved the final manuscript.

\section{Acknowledgments}

We express our gratitude to the Ministry of Research, Technology and Higher Education (SIMLITABMAS) with funding contract No. SP DIPA-042.06.1.401516/2018.

\section{Competing Interests}

The authors declare that they have no competing interests.

\section{Publisher's Note}

Veterinary World remains neutral with regard to jurisdictional claims in published institutional affiliation. 


\section{References}

1. Asha, K.K., Anandan, R., Mathew, S. and Lakshmanan, P.T. (2014) Biochemical profile of oyster Crassostrea madrasensis and its nutritional attributes. Egypt. J. Aquat. Res., 40(1): 35-41.

2. Chu, Q., Chi, ZH., Zhang, X., Liang, D., Wang, X., Zhao, Y., Zhang L. and Zhang, P. (2016) A potential role for zinc transporter 7 in testosterone synthesis in mouse Leydig tumor cells. Int. J. Mol. Med., 37(6): 1619-1626.

3. Sankako, M.K., Garcia, P.C., Piffer, R.C., Dallaqua, B., Damasceno, D.C. and Pereira, O.C. (2012) Possible mechanism by which zinc protects the testicular function of rats exposed to cigarette smoke. Pharmacol. Rep., 64(6): 1537-1546.

4. Salehi, A., Todehdehghan, T. and Esfahani, D.E. (2018) Testosterone level, testicular histology and reproductive events of Caucasian pit viper. Gloydius halys cancasicus (Serpentes: Viperidae). J. Adv. Biol., 11(1): 2155-2162.

5. Reed, S., Neuman, H., Moscovich, S., Glahn, R.P., Koren, O. and Tako, E. (2015) Chronic Zinc deficiency alters chick gut microbiota composition and function. Nutrients, 7(12): 9768-9784.

6. Brenowitz, E.A. (2013) Testosterone and BDNF interactions in the avian song control system. Neuroscience, 239(3): 115-123.

7. Roselli, C.E. (2007) Brain aromatase: Roles in reproduction and neuroprotection. J. Steroid Biochem. Mol. Biol., 106(1-5): 143-150.

8. Hess, R.A. and Cooke, P.S. (2018) Estrogen in the male: A historical perspective. Biol. Reprod., 99(1): 27-44.

9. Stocco, C. (2012) Tissue physiology and pathology of aromatase. Steroids, 77(1-2): 27-35.

10. Lindsay, W.R., Barron, D.G., Webster, M.S. and Schwabl, H. (2016) Testosterone activates sexual dimorphism including male-typical carotenoid but not melanin plumage pigmentation in a female bird. J. Exp. Biol., 219(19): 3091-3099.

11. Dissanayake, D., Wijesinghe, P.S., Ratnasooriya, W.D. and Wimalasena, S. (2009) Effects of zinc supplementation on sexual behavior of male rats. J. Hum. Reprod. Sci., 2(2): 57-61.

12. Croxford, T.P., McCormick, N.H. and Kelleher, S.L. (2011) Moderate zinc deficiency reduces testicular zip6 and zip10 abundance and impairs spermatogenesis in mice. J. Nutr., 141(3): 359-365.

13. Verma, R. and Krishna, A (2017) Effect of letrozole, a selective aromatase inhibitor, on testicular activities in adult mice: Both in vivo and in vitro study. Gen. Comp. Endocrinol., 241(15 January): 57-68.

14. Ali, E.A., Zhandi, M., Towhidi, A., Zaghari, M., Ansari, M, Najafi, M. and Deldar, H. (2017) Letrozole, an aromatase inhibitor, reduces post-peak age-related regression of rooster reproductive performance. Anim. Reprod. Sci., 183 (August): 110-117.

15. Golini, J. (2015) Rodent and human trials of the testosterone modulating experimental nutraceutical taxadrol. $J$. Biosens. Bioelectron., 6(3): 1-4.

16. Omu, A.E., Al-Azemi, M.K., Al-Maghrebi, M., Mathew, C.T., Omu, F.E., Kehinde, E.O., Anim, J.T, Oriowo, M.A. and Memon, A. (2015) Molecular basis for the effects of zinc deficiency on spermatogenesis: An experimental study in the Sprague-Dawley rat model. Indian $J$. Urol., 31(1): 57-64.

17. Dittrich, F., Ramenda, C., Grillitsch, D., Frankl-Vilches, C., Ko, M.C, Hertel, M., Goymann, W., ter Maat, A. and Gahr, M. (2014) Regulatory mechanisms of testosterone-stimulated song in the sensorimotor nucleus HVC of female songbirds. BMC Neurosci., 15(1): 1-16.
18. Carreau, S., Bouraima-Lelong, H. and. Delalande, C. (2012) Estrogen, a female hormone involved in spermatogenesis. Adv. Med. Sci., 57(1): 31-36.

19. de Ronde, W. and de Jong, F.H. (2011) Aromatase inhibitors in men: Effects and therapeutic options. Reprod. Biol. Endocrinol., 9(93): 1-7.

20. Boulanger, G., Cibois, M., Viet, J., Fostier, A., Deschamps, S., Pastezeur, S., Massart, C., Gschloessl, B., GautierCourteille, C. and Paillarda, L. (2015) Hypogonadism associated with Cyp19a1 (Aromatase) post-transcriptional upregulation in Celf1-KO mice. Mol. Cell. Biol., 35(18): 3244-3532.

21. Adeldust, H., Farzinpour, A., Farshad, A., Rostamzadeh, J. and Lopez-Bejar, M. (2017) Increased sperm cell production in aging roosters by oral treatment with an aromatase inhibitor and a natural herbal extract designed for improving fertility. Reprod. Domest. Anim., 52(4): 58-60.

22. Rosati, L., Agnese, M., Di Fiore, M.M., Andreuccetti, P. and Prisco, M. (2016) P450 aromatase: A key enzyme in the spermatogenesis of the Italian wall lizard, Podarcis sicula. J. Exp. Biol., 219(15): 2402-2408.

23. Ogunlesi, M., Okiei, W., Ofor, E. and Awonuga, O. (2009) Determination of the concentrations of zinc and Vitamin C in oysters and some medicinal plants used to correct male factor infertility. J. Nat. Prod., 2(1): 89-97.

24. Jardi, F., Laurent, M.R., Kim, N., Khalil, R., Bundel, D.D., Eeckhaut, A.V., Helleputte, L.V., Deboel, L., Dubois, V., Schollaert, D., Decallonne, B., Carmeliet, G., Bosch, L.V.D., D'Hooge, R., Claessens, F. and Vanderschueren, D. (2018) Testosterone boosts physical activity in male mice via dopaminergic pathways. Sci. Rep., 8(1): 1-14

25. Antonio-Cabrera, E. and Paredes, R.G. (2014) Testosterone or oestradiol implants in the medial preoptic area induce mating in noncopulating male rats. J. Neuroendocrinol., 26(7): 448-458.

26. Juntti, S.A., Tollkuhn, J., Wu, M.V., Fraser, E.J., Soderborg, T., Tan, S., Honda, S., Harada, N. and Shah, N.M. (2010) The androgen receptor governs the execution, but not programming, of male sexual and territorial behaviors. Neuron., 66(2): 260-272.

27. Kumar, N. and Singh, A.K. (2016) Role of zinc in male infertility: Review of the literature. Indian J. Obstet. Gynecol. Res., 3(2): 167-171.

28. Fallah, A., Mohammad-Hasani, A. and Colagar, A.H. (2018) Zinc is an essential element for male fertility: A review of $\mathrm{Zn}$ roles in men's health, germination, sperm quality, and fertilization. J. Reprod. Infertil., 19(2): 69-81.

29. Schulster, M., Bernie, A.M. and Ramasamy, R. (2016) The role of estradiol in male reproductive function. Asian $J$. Androl., 18(3): 435-441.

30. Bhasin, S., Cunningham, G.R., Hayes, F.J., Matsumoto, A.M., Snyder, P.J., Swerdloff, R.S. and Montori, V.M. (2010) Testosterone therapy in men with androgen deficiency syndromes: An endocrine society clinical practice guideline. J. Clin. Endocrinol. Metab., 95(6): 2536-2559.

31. Ketterson, E.D. (2014) Male and female testosterone is one sex made in the image of the other? A comment on Goymann and Wingfield. Behav. Ecol., 25(4): 702.

32. Domonkos, E., Hodosy, J., Ostatníková, D. and Celec, P. (2018) On the role of testosterone in anxiety-like behavior across life in experimental rodents. Front. Endocrinol., 9(441): 1-10.

33. Hau, M., Ricklefs, R.E., Wikelski, M., Lee, K.A. and Brawn, J.D. (2010) Corticosterone, testosterone and life-history strategies of birds. Proc. R. Soc. B Biol. Sci., 277(1697): 3203-3212. 